\title{
Digitalisasi Kitab Nadham Batu Ngompal Karya TGKH. Muhammad Zainuddin Abdul Madjid Berbasis OPF Flipbook
}

\author{
Hariman Bahtiar'1, Aswian Editri Sutriadi2, Muhammad Djamaluddin ${ }^{3}$ \\ 1,2Program Studi Sistem Informasi, Universitas Hamzanwadi \\ 3Program Studi Teknik Informatika, Universitas Hamzanwadi \\ *harimaob@gmail.com
}

\begin{abstract}
Abstrak
TGKH. Muhammad Zainuddin Abdul Madjid merupakan salah satu tokoh dan ulama kharismatik yang berasal dari Pulau Lombok. Banyak karya yang sudah dihasilkan oleh beliu selama hidupnya, untuk dijadikan pedoman bagi murid dan para jamaah yang beliu pimpin. karya-karya Maulana Syaikh masih menggunakan media konvensional berupa kertas. Dengan media konvesional tersebut, kebanyakan dengan seringnya dipakai atau penempatan yang tidak tepat, maka bisa membuat media menjadi rusak. Pemanfaatan teknologi untuk menjaga dan melestarikan karya-karya peninggalan tokoh dan ulama besar kharismatik serperti TGKH. Muhammad Zainuddin Abdul Madjid sangat penting. Salah satu karya beliu adalah Nazam Batu Ngompal, Nadham "Batu Ngompal" adalah salah satu kitab yang menjelaskan tata cara membaca Al-qur'an secara fasih dan tartil. Dengan dibuatkannya kitab Nadham Batu Ngompal dalam bentuk digital ini membantu santri dan para jamaah untuk membaca karya-karya beliu dari manapun. Salah satu kelebihan dari e-book Nadham Batu Ngompal adalah ebook ini menggunkan format OPF filip book sehingga ketika kita buka seolah-olah kita membuka buku aslinya, dan selain menyediakan teksnya, e-book ini juga menyediakan fasilitas suara bacaan syair yang ada dalam buku. Jadi selain kita membaca juga bisa mendengarkan suara lantunan syair yang ada di dalam isi buku sekaligus.
\end{abstract}

Kata kunci: Nadham Batu Ngompal, Digitalisasi, OPF Flipbook

\begin{abstract}
TGKH. Muhammad Zainuddin Abdul Madjid is one of the charismatic figures and scholars who came from Lombok Island. Many works have been produced by the purchase during his life, to be used as a guide for students and pilgrims who buy and lead. Maulana Shaykh's works still use conventional media in the form of paper. With this conventional media, mostly with frequent use or improper placement, it can make the media become damaged. The use of technology to preserve and preserve the works of charismatic figures and great scholars such as TGKH. Muhammad Zainuddin Abdul Madjid is very important. One of the works of purchase is Nazam Batu Ngompal, Nadham "Batu Ngompal" is one of the books that explain how to read the Qur'an fluently and in tartil. With the creation of the Nadham Batu Ngompal book in digital form, it helps students and worshipers to read your purchases from anywhere. One of the advantages of the Nadham Batu Ngompal e-book is that this e-book uses the OPF flipbook format so that when we open it as if we are opening the original book, and besides providing the text, this e-book also provides sound poetry reading facilities in the book. So besides reading, we can also listen to the sound of the poetry that is in the contents of the book at once
\end{abstract}

Keywords: Nadham Batu Ngompal, Digitalisation, OPF Flipbook

\section{Pendahuluan}

Pulau Lombok sebagai salah satu pulau yang mempunyai potensi yang cukup besar untuk dijadikan objek wisata. Dengan keindahan alam dan keanekaragaman budaya yang dimilikinya menjadikan pulau lombok sebagai salah satu destinasi tujuan wisata primadona di indonesia[1]. Selain terkenal dengan pesona 
pantainya, pulau lombok juga memiliki banyak peninggalan-peninggalan yang memiliki nilai sejarah yang masih terpelihara sampai sekarang. Sebagai salah satu contohnya adalah rumah adat tradisional desa belek sembalun lawang[2][3]. Berbagai macam adat budaya, seni dan karya-karya tokoh-tokoh agama masih terpelihara sampai sekarang. Salah satu tokoh atau ulama yang memiliki peran besar dalam menyebarkan agama islam dan memiliki pengaruh besar di pulau lombok adalah TGKH. Muhammad Zainuddin Abdul Madjid.

TGKH. Muhammad Zainuddin Abdul Madjid adalah seorang ulama karismatik yang ada di pulau Lombok dan merupakan pendiri Nahdlatul Wathan, organisasi terbesar yang ada di propensi Nusa Tenggara Barat. Karya-karya Maulana Syaikh TGKH. Muhammad Zainuddin Abdul Madjid, seperti kitab-kitab beliau adalah suatu amalan yang rutinitas dibaca oleh santri dan santriwati bahkan jamaah Nahdlatul Wathan, sebagai doa dan pelajaran yang diamalkaan setiap selesai ibadah[4][5][6]. Banyak karyakarya yang sudah beliau hasilkan baik itu dalam bahas indonesia, bahasa arab dan bahasa sasak. Salah satu karya beliau dalam bahasa sasak adalah buku atau kitab Nadham Batu Ngompal. Batu Ngompal merupakan sebuah buku yang ditulis dalam bahasa Sasak, berisikan petunjuk atau tata cara dalam membaca AlQuran yang biasa disebut dengan ilmu tajwid. Buku tersebut diperuntukkan bagi siapa saja yang ingin memperdalam pemahamannya terhadap Al-Qur'an[7].
Kitab Nadham Batu Ngompal ini sangat menarik, mudah dipelajari dan dipahami karena disampaikan dalam bentuk syair tentang tata cara dalam membaca Al-Quran. Kitab Nadham ini sering di gunakan oleh murid, jamaah dan masyarakat dalam belajar ilmu tajwid, diedarkan dalam bentuk buku. Seiring dengan perkembangan teknologi informasi, karya kitab Nadham Batu Ngompal perlu dibuat dalam betuk digital. Media digital itu sendiri memiliki beberapa keuntungan, antara lain seperti tidak mudah rusak, mudah dibawa kemana-mana dan dapat diakses kapanpun dan dimanapun karena media digital sekarang ini sudah menjadi bagian dari aktifitas sebagian besar masyarakat.

\section{Tinjauan Pustaka}

\subsection{Penelitian Terkait}

Penelitian yang di lakukan oleh Hariman Bahtiar, Muhamad Wasil dan Bambang Harianto dalam jurnal yang berjudul "Digitalisasi Karya TGKH. Muhammad Zainuddin Abdul Madjid berbasis mobile sebagai media pembelajaran interaktif untuk pelestarian peninggalan pendiri Nahdlatul Wathan" yang membahas tentang digitalisasi karya TGKH. Muhammad Zainudin Abdul Madjid berbasis mobile sebagai media pembelajaran interaktif untuk pelestarian peninggalan pendiri Nahdlatul Wathan menjadi salah satu solusi akan membantu murid-murid beliau yang notabennya tidak memiliki kitab tersebut dan terhalang dengan jarak dan waktu[4].

Menurut Caroline T. Schroeder di penelitiannya yang berjudul The Digital Humanities as Cultural 
Capital: Implications for Biblical and Religious Studies "digitalisasi adalah mengacu pada proses menterjemahkan suatu potongan informasi seperti sebuah buku, rekaman suara, gambar atau video, ke dalam bit-bit. Bit adalah satuan dasar informasi di dalam suatu sistem komputer[8]. Sedangkan menurut S. Bandi, M. Angadi, and J. Shivarama "digitisasi adalah proses konversi dari segala bentuk dokumen tercetak atau yang lain ke dalam penyajian bentuk digital[9].

\subsection{Landasan Teori}

\subsubsection{Digitalisasi}

Seiring dengan kemajuan teknologi, media sosial dan peralatan teknologi lainnya muncul sebagai pengganti metode tatap muka untuk memudahkan masyarakat dalam menyebarkan informasi. Dengan adanya media sosial dan peralatan teknologi lainnya, maka proses penyebaran informasi menjadi berkembang dan berubah dari format analog menjadi digital. Proses perubahan dari dokumen tercetak menjadi dokumen elektronik sering disebut dengan proses digitalisasi dokumen. Proses digitalisasi dokumen ini tentu tidak diperlukan lagi apabila dokumen elektronik sudah menjadi standar dalam prosesdokumentasi sebuah organisasi[9].

Dalam bidang perpustakaan, proses digitalisasi adalah kegiatan mengubah dokumen tercetak menjadi dokumen digital. Proses digitalisasi ini dapat dilakukan terhadap berbagai bentuk koleksi atau bahan pustaka seperti, peta, naskah kuno, foto, karya seni patung, audio visual, lukisan, dan sebagainya. Untuk mendigitalisasi masing-masing bentuk koleksi tersebut tentunya digunakan cara yang berbeda. Misalnya untuk karya seni patung dan lukisan, biasanya menggunakan kamera digital atau merekamnya dalam bentuk gambar bergerak sehingga menghasilkan foto digital atau video. Sedangkan untuk dokumen cetak lain biasanya menggunakan mesin scanner[10].

\subsubsection{OPF FlipBook}

Format ini dikenal pula sebagai OPF FlipBook. OPF adalah suatu format buku elektronik yang berbasis pada XML yang dibuat oleh sistem buku elektronik. Buku elektronik dalam format ini dikenal saat FlipBooks sebagai peranti lunak penyaji menampilkan buku dalam format 3D yang bisa dibuka-buka (flipping)[11]. Terdapat suatu proyek yang sedang berjalan yang berupaya agar format OPF ini dapat dibaca menggunakan penjelajah Internet standar (semisal: Mozilla, Firefox, atau Microsoft Internet Explorer), tanpa perlu adanya perlengkapan (peranti lunak, plugin) tambahan. Saat ini untuk melihat buku elektronik dalam format OPF sehingga diperoleh rasa benar-benar membuka buku (flipping experience) diperlukan peranti lunak penyaji pada sisi klien atau pengguna. 


\subsubsection{TGKH. Muhammad Zainuddin Abdul Madjid dan Karya Nadham Batu Ngompal}

TGKH. Muhammad Zainuddin Abdul Madjid selain tergolong tokoh ulama dengan bobot keilmuan yang mendalam, juga termasuk penulis dan pengarang yang produktif. Sebagai salah seorang ulama besar di pulau lombok, ia memiliki kewibawaan yang sangat tinggi ia juga sangat dihormati dan disegani. Oleh sebab itu, beliau memiliki ribuan pengikut, bukan hanya dari pulau lombok saja, tetapi juga dari pulaupulau diluar pulau lombok. TGKH. Muhammad Zainuddin Abdul Madjid dalam melakukan aktivitas di bidang pendidikan, sosial dan dakwah, ia juga tidak lupa menulis berbagai kitab sebagai rujukan bagi para santri di madrasah NWDI dan NBDI. Karya-karyanya memang tidak berbentuk kitab-kitab yang besar, yang berisi kajian-kajian yang panjang lebar pembahasannya, tetapi karyanya lebih merupakan kajian-kajian dasar dan biasanya dalam bentuk syair nazham-nazham berbahasa arab. Di samping itu juga, terdapat kitab yang berisi nazham dalam dua bahasa yaitu bahasa Arab dan Melayu[7].

Nadham "Batu Ngompal" adalah salah satu kitab yang menjelaskan tata cara membaca Al-qur'an secara fasih dan tartil, kitab yang sama berjudul "Anak nunggal taqrirat Batu ngompal" keduanya di tulis dengan Arab melayu. juga terdapat kitab tajwid berjudul "Nailul Athfal" yang di karang oleh Al-magfurulahu Maulana Asysyaikh TGKH. Muhammad Zainuddin Abdul madjid sekitar tahun 70-an di desa kelahiran beliau yaitu Desa Bermi, Pancor, Lombok Timur, Nusa Tenggara Barat (NTB). Ketiga kitab tersebut menunjukkan perhatiannya yang cukup besar dalam bidang baca tulis Al-qur'an.

Nadham Batu Ngompal merupakan sebuah buku yang ditulis dalam bahasa Sasak, berisikan petunjuk atau tata cara dalam membaca AlQuran yang biasa disebut dengan ilmu tajwid. Buku tersebut diperuntukkan bagi siapa saja yang ingin memperdalam pemahamannya terhadap Al-Qur'an. Buku-buku yang ditulis oleh TGKH. Muhammad Zainuddin Abdul Madjid berfungsi sebagai bahan dalam mempelajari ilmu-ilmu agama. Di samping itu juga dapat dipergunakan sebagai pegangan dalam menjalani syariat-syariat islam yang telah diperintahkan kepada Umat manusia. Dengan kata lain, buku-buku tersebut banyak memberikan manfaat bagi masyarakat pembaca, kususnya bagi para murid beliau.

\subsubsection{Tahapan Penelitian}

Adapun tahapan dari penelitian ini meliputi beberapa tahapan penelitian diantaranya :

1. Tahap pengumpulan data

Merupakan tahap pengumpulan data-data dan informasi tentang karya TGKH. Muhammad Zainuddin Abdul Madjid, khususnya karya kitab Nazam Batu Ngompal.

2. Tahap Analisis

Tahapan analisis sistem merupakan tahap mengidentifikasi dan menentukan rancangan 
proses digitalisasi dari kitab Nazam Batu Ngompal karya TGKH. Muhammad Zainuddin Abdul Madjid.

3. Tahap Digitalisasi dan Pembuatan Sistem Tahap Proses digitalisasi buku atau kitab karya TGKH. Muhammad Zainuddin Abdul Madjid ke dalam bentuk teks dan gambar dengan cara menulis ulang buku atau kitab tersebut dilanjutkan dengan desain dan pembuatan sistem.

4. Experimen dan Pengujian

Hasil yang telah dilakukan, di uji coba untuk melihat apakah system yang dihasilkan dapat sesuai dengan yang diinginkan peneliti.

5. Evaluasi

Setelah dilakukan pengujian dan experimen terhadap hasil yang dilakuan, maka bisa dilihat perbedaan dari hasil yang dilakukan sebelumnya, apakah apakah dengan digitalisasi model interaktif ini dapat membantu santri dalam mempelajari karyakarya TGKH. Muhammad Zainuddin Abdul Madjid.

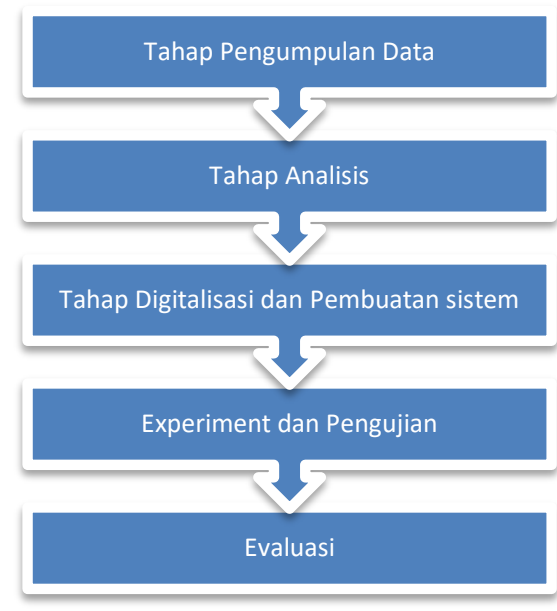

Gambar 1. Tahapan Penelitian

\section{Metode Penelitian}

\subsection{Metode Penelitian}

Untuk mendapatkan data yang benar - benar bisa digunakan, akurat, dan relevan terhadap hasil nyata, maka peneliti menerapkan beberapa cara dalam pengumpulan data diantaranya adalah :

1. Observasi

Observasi merupakan suatu teknik pengumpulan data melalui pengamatan dan pencatatan terhadap suatu peristiwa yang berhubungan dengan object penelitiannya. Pengamatan dilakukan Yayasan Pendidikan Hamzanwadi Pondok Pesantren Darunnahdlatain Nahdlatun Wathan Pancor Kabupaten Lombok Timur

2. Interview

Interview merupakan suatu tekni pengumpulan data melalui tatap muka dan tanya jawab langsung dengan sumber data yaitu Pengurus Yayasan Pendidikan Hamzanwadi Pondok Pesantren Darunnahdlatain Nahdlatun Wathan Pancor Kabupaten Lombok Timur.

3. Studi Pustaka

Suatu metode yang dilakukan degan membaca dan mempelajari literatur, dokuman - dokumen atau buku - buku yang bisa digunakan sebagai petunjuk dalam melancarkan penelitian.

\subsection{Proses Sistem Digitalisasi}

Beberapa tahapan yang dapat dilakukan untuk mendigitalisasi karya TGKH. Muhammad 
Zainuddin Abdul Madjid Nadham Batu Ngompal adalah sebagai berikut :

1. Pengumpulan informasi dan bahan-bahan penelitian karya TGKH. Muhammad Zainuddin Abdul Madjid khususnya kitab Nazam Batu Ngompal.

2. Tahap Analisis, pada tahap ini karya TGKH Muhammad Zainuddin Abdul Madjid, dilakukan proses analisis dan prancangan untuk digitalisasi dalam bentuk ebuku Nadham Batu Ngompal,.

3. Tahap desain dan proses, pada tahapan ini dilakukan proses digitalisasi baik dalam bentuk teks maupun gambar dan suara dengan menggunakan komputer (baik hardware maupun software) dan scaner. Hasil dari digitalisasi dibuat dalam bentuk plugin-plugin untuk mempermudah desain dan tampilan dalam berbagai platform.

\section{Hasil dan Pembahasan}

Untuk membuka e-book Nadham Batu Ngompal karya TGKH. Muhammad Zainuddin Abdul Madjid bisa dilakukan dengan dua cara yaitu mengklik ikon yang ada di desktop seperti ditunjukkan pada gambar 2. dan bisa juga di akses melalui website dan mobile.

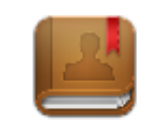

Nahdam Batu Ngompal.exe

Gambar 2. Ikon e-book Nadham Batu Ngompal
Maka akan muncul tampilan e-book Nadham Batu Ngompal seperti ditunjukan pada gambar 3. E-book Nadham Batu Ngompal ini sudah memiliki futur yang lengkap. E-book ini menggunkan format OPF filip book sehingga ketika kita buka seolah-olah kita membuka buku aslinya.

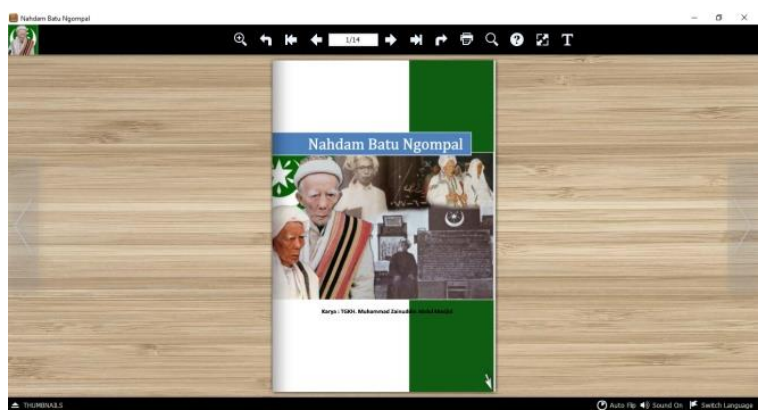

Gambar 3. Halaman depan Nadham Batu Ngompal

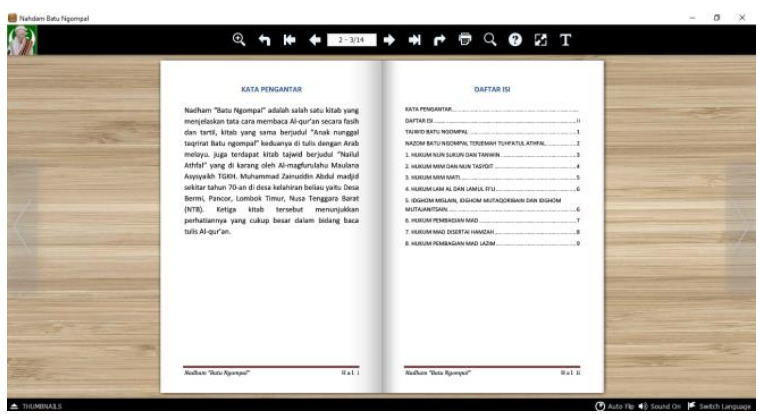

Gambar 4. Halaman Kata Pengantar dan daftar isi Nadham Batu Ngompal

Salah satu kelebihan dari e-book Nadham Batu Ngompal ini selain menyediakan teksnya, e-book ini juga menyediakan fasilitas suara bacaan syair yang ada dalam buku. Jadi selain kita membaca juga bisa mendengarkan suara lantunan syair yang ada di dalam isi buku sekaligus. 


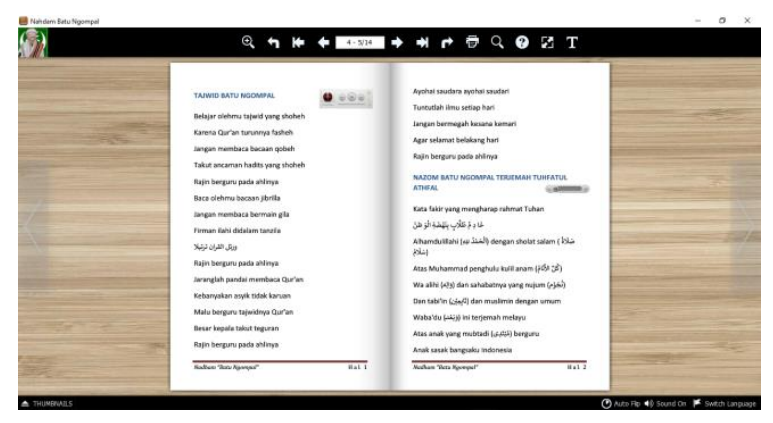

Gambar 5. Halaman isi Nadham Batu Ngompal

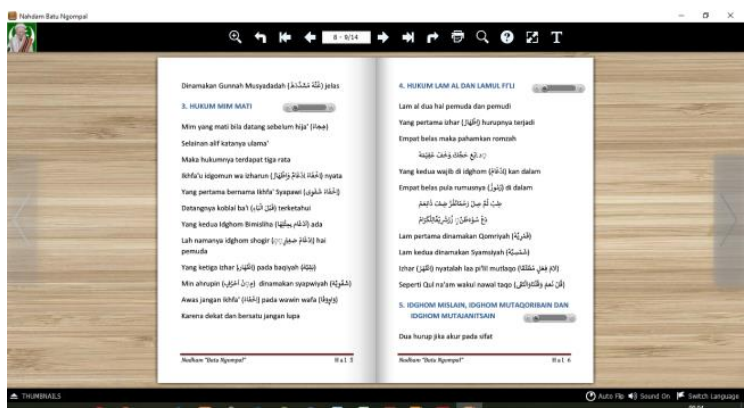

Gambar 6. Halaman isi Nadham Batu Ngompal

\section{Kesimpulan.}

Pemanfaatan teknologi untuk menjaga dan melestarikan karya-karya peninggalan tokoh dan ulama besar kharismatik serperti TGKH. Muhammad Zainuddin Abdul Majdid sangat penting. Apalagi 2017 beliau dianugrahi gelar pahlawan nasional. Salah satu karya beliu adalah Nazam Batu Ngompal, Nadham "Batu Ngompal" adalah salah satu kitab yang menjelaskan tata cara membaca Al-qur'an secara fasih dan tartil. Dengan dibuatkannya kitab Nadham Batu Ngompal dalam bentuk digital ini membantu santri dan para jamaah untuk membaca karya-karya beliu dari manapun. Salah satu kelebihan dari e-book Nadham Batu Ngompal adalah e-book ini menggunkan format OPF filip book sehingga ketika kita buka seolaholah kita membuka buku aslinya, dan selain menyediakan teksnya, e-book ini juga menyediakan fasilitas suara bacaan syair yang ada dalam buku. Jadi selain kita membaca juga bisa mendengarkan suara lantunan syair yang ada di dalam isi buku sekaligus.

\section{Daftar Pustaka}

[1] Hariman Bahtiar, "Sistem Informasi Wisata dan Budaya Pulau Lombok dengan Multimedia Intraktif Untuk Meningkatkan Kunjungan Wisata," Infotek J. Inform. dan Teknol., vol. 1, no. 1, pp. 1-10, 2018.

[2] M. and H. Bahtiar, "Visualization Of The Traditional House Architecture Of Belek Sembalun Lawang Village By Using 3D Animation Visualization Of The Traditional House Architecture Of Belek Sembalun Lawang Village By Using 3D Animation," Conf. Ser., vol. 1539, 2020.

[3] Hariman Bahtiar;Muhammad Djamaludin; M Rizal Supriandi, "Pengenalan Arsitektur Rumah Tradisional Desa Belek Sembalun Lawang Lombok Dengan Menggunakan Animasi 3d Menggunakan Blender Sebagai Media Pembelajaran," Infotek J. Inform. dan Teknol., vol. 3, no. 1, 2020.

[4] Hariman Bahtiar; Muhamad Wasil; Bambang Harianto, "Digitalisasi Karya TGKH. Muhammad Zainuddin Abdul Madjid berbasis mobile sebagai media pembelajaran interaktif untuk pelestarian peninggalan pendiri Nahdlatul Wathan," 
Infotek J. Inform. dan Teknol., vol. 88, no. 5, pp. 427-434, 2019.

[5] Hariman Bahtiar and L. Kerta Wijaya, "Mobile Based Geographic Information System for mapping and data Mobile Based Geographic Information System for mapping and data collection Towards 4 . 0 Industry," Conf. Ser., vol. 1539, pp. 0-5, 2020.

[6] M. H. Dr. Khirjan Nahdi, Nahdlatul Wathan \& Peran Modal (Studi EtnogafiHistoris Modal Spritual \& Sosiokultural). Insyira Yogyakarta, 2002.

[7] M. Noor M., Habib M., dan Harfin Zuhdi, "visi kebangsaan." Jakarta Timur :

Pondok Pesantren Nahdlatul Wathan Jakarta, 2014.

[8] C. T. Schroeder, "The Digital Humanities as Cultural Capital: Implications for Biblical and Religious Studies," J. Relig. Media Digit. Cult., vol. 5, no. 1, pp. 21-49, 2016.

[9] S. Bandi, M. Angadi, and J. Shivarama, "Best Practices in Digitization: Planning and Workflow Processes," pp. 332-339, 2015.

[10] A. Gunawan, "Digitalisasi Naskah Nusantara dan Creative Commons: Proyeksi Penerapannya di Indonesia," no. 2009, pp. 1-15, 2012.

[11] M. Burch and D. Weiskopf, "A flip-book of edge-splatted small multiples for visualizing dynamic graphs," ACM Int. Conf. Proceeding Ser., vol. 2014-Augus, no. August, pp. 29-38, 2014. 